\title{
THE TRANSACTION COST THEORY :A FIELD RESEARCH ON SMALL-SCALE ANIMAL PRODUCER'S
}

\author{
Ayhan YASAN \\ Anka Consultancy Group (ADG), Turkey
}

\begin{abstract}
This study aims to explain Turkish small-scale animal producer's commercial helplessness while exploring the attributes resulting in high transaction costs. It also investigates producer's need for an integrated meat-processing plant in the Anatolian city of Eskişehir in Turkey. A field research was conducted on randomly selected 857 small-scale animal producers in the region. A structural equation model is constructed so as to precisely test the attributional influences of producer's commercial helplessness on sales channel mistrust and need for an integrated meat-processing plant; as well as these of sales channel convenience and commercial helplessness on transaction cost. Exploratory and confirmatory factor analyses were employed. The final measurement model was developed by secondorder confirmatory factor analysis. The findings have shown that commercial helplessness was positively influenced by need for plant and sales channel mistrust while it positively ad significantly affects transaction cost. In addition, sales channel convenience is found to have a significant effect on "transaction cost" in the negative direction. Collectively, these findings suggest that there is a need for establishing an integrated meat-processing plant in the region.
\end{abstract}

Keywords: Transaction Cost Economics, Commercial helplessness, Governance, Integrated meatprocessing plant, Small-scale animal producers, Turkey.

\section{INTRODUCTION}

Today, small-scale animal producers in Turkey often feel commercial helplessness while selling their animals in spot markets (Yasan, 2018). These markets are characterized by unrepeated relationship between buyer and seller (Williamson, 1985). Producers face high levels of transaction costs (TCs) in such markets since they find themselves in a difficult position when there are always the problems of bounded rationality, opportunism, asset specificity, behavioural uncertainty, complexity and infrequency in the presence of asymmetrical information (Hobbs, 1996b).

Chen et al. (2006) explained that human nature and the environment of exchange can cause market failure due to unacceptably high TCs in transaction processes, while differences in the character of exchange level can also influence TCs. Cadeaux and $\mathrm{Ng}$ (2012) have found that high environmental uncertainty creates an asymmetry of information between the transacting parties; asymmetric information and/or bounded rationality limits rational decision-making for both parties; and that small numbers bargaining and environmental uncertainty increases the potential for opportunism. Williamson (1979) states that it is the combination of bounded rationality, opportunism and asset specificity, in the presence of information asymmetry, that leads to TCs and market failure. Williamson (1975) has determined that market failure attracts vertical integration.

As for the Food and Agriculture Organization (FAO) (2009a), small-scale animal producers are not able to work satisfactorily since they prefer informal arrangements i.e. spot markets where the existence of social capital has a major role. Spot market transactions involve hard bargaining between parties whose identities are irrelevant because there is no dependency between the parties (Williamson, 1991). Therefore, spot markets are self-regulated and involve only short-term relationship and no compromise between sellers and buyers once the transaction is completed (FAO, 2009b; Vilpoix, 2013).

According to Transaction Cost Economics; asset specificity, opportunism, and risk preference lead smallscale animal producers to choose between hierarchical governance (e.g. vertical integration) and spot market contracting (Geyskens et al., 2006). This suggests that small-scale animal producers have to find institutional arrangements such as vertical integration that can ensure price and quantity stability in their production (Vilpoix, 2013). Therefore, vertical integration can facilitate coordination and minimize uncertainty in producer's transactions. These integration systems have been emerging between smallscale animal producers and integrated meat-processing (IMP) plants in many developed countries, 

shifting them from the traditional spot market to short-term or longer-term contractual arrangement (Gong et al., 2007).

Animal husbandry is an integral part of Turkey's agriculture sector. Many rural people depend on animal farming for their livelihoods. However, the share of the sector gradually decreased during transition process from agricultural society, i.e. when animal husbandry sector played a significant role in the national economy, to industrial society (Selli et al., 2010). Due to high TCs, most of the producers have left their villages and moved to large cities. Thus, a decrease in the number of cattle has been observed countrywide.

The participation of Turkish small-scale animal producers in formal markets is currently limited. Therefore, the Turkish government has undertaken initiatives to re-strengthen animal husbandry in Anatolia by supporting the establishment of IMP plants in Anatolia to reverse the immigration; thereby creating jobs, sustaining productivity; leading to an increase in food security and development of an efficient marketing system for animal producers.

Small-scale animal producers in Turkey feel commercially helpless in economizing their products, since they are not tradesmen and do not know how to sell and perform well at spot markets (Yasan, 2018). Therefore, this study will investigate the attributes influencing commercial helplessness and TCs of Turkish small-scale animal producers while elaborating on their need to vertically integrate with an IMP plant in the region as a governance structure.

The remaining sections of the paper are organized as follows: The author presents literature review on TCs, governance structures and vertical integration in animal husbandry sector in Section 2. The author provides the four hypotheses of the research, information about sampling and data collection in Section 3. Section 4 is dedicated to the research framework elaborating on the dimensions and variables of the proposed model. In Section 5, the author tabulates the details of the analyses and gives the findings. Finally, conclusions are presented in Section 6 including the limitations of the study and the focus of further studies.

\section{LITERATURE REVIEW}

The TCE approach has its roots in the original ideas of Coase (1937) and uses the concept of TCs to explain the organization of economic transactions and the way in which they interact along a supply chain (Hobbs, 1996b). TCE suggests that many business exchanges can be characterized by incomplete, imperfect or asymmetrical information (Hobbs, 1996b). Hobbs (1997), MacInnis (2004) and Jabbar et al. (2006), in their studies, discuss that TCs have complex nature and are not easy to separate from each other. They state that TCs are neither easily quantifiable by putting in a mathematical form nor readily available on financial records.

Hobbs (1996b) have placed TCs in three distinct categories, namely: "information costs" (IC), "negotiation costs" (NC); and "monitoring costs" (MC). He suggests that absolute minimization of TCs is never possible. Various definitions of TC are given in Table 1. 
Table 1. Various Definitions of a Transaction Cost (TC)

\begin{tabular}{|c|c|c|}
\hline Year & Author & Definition \\
\hline 1937 & Coase & Total costs incurred while using the price mechanism. \\
\hline 1960 & Coase & Sum of all costs while carrying out exchange. \\
\hline 1969 & Arrow & Costs for organising and running the economic system. \\
\hline 1990 & Eggertson & $\begin{array}{l}\text { Costs that arise when individuals exchange ownership rights for economic assets and enforce their } \\
\text { exclusive rights. }\end{array}$ \\
\hline 1995 & $\begin{array}{l}\text { Jaffee and } \\
\text { Morton }\end{array}$ & Sum of transfer costs and MCs. \\
\hline 1997 & North & $\begin{array}{l}\text { Costs of measuring the valuable attributes of what is being exchanged, and the costs of protecting } \\
\text { rights and policing and enforcing agreements. }\end{array}$ \\
\hline 2000 & $\begin{array}{l}\text { Allen and } \\
\text { Lueck }\end{array}$ & $\begin{array}{l}\text { Costs of enforcing and maintaining property rights, i.e. regardless of whether a market exchange takes } \\
\text { place or not, and include the deadweight losses that result from enforcing property rights. }\end{array}$ \\
\hline 2002 & Fiani & $\begin{array}{l}\text { Costs that agents face every time they turn to the market, such as the costs of negotiating, drafting and } \\
\text { enforcing a contract. }\end{array}$ \\
\hline 2004 & Nkhori et al. & Sum of ICs, NCs, MCs and enforcement costs. \\
\hline 2006 & Jabbar et al. & $\begin{array}{l}\text { Physical marketing costs, e.g. transport and storage costs, arising from the coordination of the } \\
\text { exchange among relevant market agents, including the cost of obtaining and processing market } \\
\text { information, negotiating contracts, monitoring agents, and enforcing contracts. }\end{array}$ \\
\hline 2007 & Walter et al. & $\begin{array}{l}\text { Sum of logistic costs including cash payments; and amortized costs associated with post-production } \\
\text { handling, packaging, storage, inventory carrying and transportation. }\end{array}$ \\
\hline 2008 & Alene et al. & $\begin{array}{l}\text { The embodiment of barriers to market participation by resource-poor smallholders, which has been } \\
\text { used as a definitional characteristic of smallholders and the factors responsible for significant market } \\
\text { failures in developing countries. }\end{array}$ \\
\hline 2008 & Singh & $\begin{array}{l}\text { Costs associated with market exchange, including the cost of searching for options, negotiating } \\
\text { contracts and enforcing agreements. }\end{array}$ \\
\hline 2012 & Arinloye et al. & $\begin{array}{l}\text { Comparative costs of planning, adapting and monitoring task completion under alternative } \\
\text { governance structures. }\end{array}$ \\
\hline
\end{tabular}

\section{Governance}

Economizing on TCs is at the central point of the TCE (Williamson, 1975, 1985). This can be achieved by choosing a governance structure such as market, hierarchy, or hybrid. (Walker and Weber, 1984). Williamson (1985) has stated that a governance structure involves the design of the particular mechanisms supporting an economic transaction where there is an exchange of property rights.

Several factors affect the choice of a mode of governance structure by parties involved in a transaction. The forecasted complexity of regarding tasks among partners and of coordinating across organizational boundaries has been the major factor in the choice of a specific mode of governance and in the design of mechanisms for monitoring the arrangement (Gulati and Singh, 1998). On the other hand, the effect of the institutional environment on the choice a mode of governance structure is still unclear in the literature (Menard, 2004).

Implementing incorrect governance structure may prevent organisations from attaining the full potential offered by the resources they control (Barney, Wright and Ketchen, 2001; Hutt et al., 2000). Therefore, Williamson (1985) has stated that, from the TCE perspective, the rational animal producer should choose a governance structure that is best performing in minimizing the production and TCs.

Similarly, Barney and Hesterly (2006) have discussed that the TCE tries to derive the optimal governance structure under a certain set of situational contingencies. In addition, Charlebois and Camp (2007) have suggested that choosing the optimal degree of integration may depend on various factors such as strategy and cost associated with uncertainty. They determined that integration is most likely to occur at the production and packing stages in the total production-distribution process where its perishability is greatest.

Williamson (1975) has discussed that the key motivation for organisations to vary governance structures is their intention to economize on TCs. He has identified three categories of costs, namely ex-ante costs (i.e. costs associated with forming and maintaining contractual and employment relationships); the unit price of the goods/service; and ex-post costs (i.e. costs associated with monitoring quality and performance). He has stated that different governance structures may imply a trade-off. He has concluded that when organisational hierarchies are more exposed to bureaucratic inefficiencies, market-based 
Journal of Global Strategic Management | V. 12 | N. 2 | 2018-December| isma.info | 005- 026 | DOI: 10.20460/JGSM.2019.265 relationships have a higher risk of opportunistic behaviour by providers. Moreover, Abraham and Taylor (2001) have found that the more bureaucratic inefficiencies organisations experience, and the less vulnerable they are to the opportunism costs associated with market-based contracting; the higher the incentive to outsource.

As the nature of vertical co-ordination within the UK beef marketing chain evolves in response to changing transaction costs, so the beef marketing chain should become more responsive to consumer concerns. This should result in beef products which better meet the requirements of consumers in terms of consistent product quality and food safety, and which go some way towards meeting any concerns regarding animal welfare on farms.

Two poles in the continuum, i.e. spot market transactions and vertically coordinated agricultural organization, lie as alternative ways of co-ordinating economic activity, from strategic alliances and formal written contracts, to vertical integration (Hobbs, 1996b). Barringer and Harrison (2000) have suggested "make or buy or partner" decision and introduced the concept of "trust" that alliance partners may develop after successful transactions.

Extensive literature exists on measuring TCs. However, studies related to modes of governance structure in the animal husbandry are limited. Nevertheless, the following studies investigating the effect of a governance structure on TCs, have been conducted.

Hobbs (1996a) has suggested that strategic alliance partnerships between producer marketing groups, processors and retailers improve the two-way flow of information concerning the type of product which consumers require and the standards under which it is produced.

Hobbs (1996b) states that different supply channels impose different types and levels of TCs on beef processors. She has concluded that ease of traceability decreases the MCs for processors. In addition, her findings have shown that minimized handling of cattle reduces the potential for carcass damage and shrinkage related to stress.

In a third study, Hobbs (1997) compared marketing options for cattle producers. She measured the relative effect of various TCs on producers' choice between live-ring and direct-to-packer sales. Her overall results have demonstrated that the live-ring sales do not impose significant ICs on beef producers. However, the risk that the cattle may not reach the producer's reserve price and would have to be transported back to the farm to be sold at a later date raised NCs for producers. The opportunity cost (OC) of producers' time in travelling to, from and in attending the market is determined to be an important NC. It is suggested that the role of procurement staff in meat packing firms can reduce these costs for producers selling directly to companies. The most important MC of producers is highlighted to be grade uncertainty.

Gong et al. (2007) have tried to identify the significant factors affecting producers' selection of cattle marketing channels. They determined that TCs were significant. Their model has depicted significant relationships between economic and social variables, and choices of cattle marketing channels. They have confirmed that ICs and NCs influence producers' overall choices of spot market sale or forward contract with processors. In addition, high TCs borne by Chinese producers make many of them to use spot market to sell their cattle. Those producers who are willing, and can afford, to incur higher TCs are determined to choose forward contracts. Moreover, socio-economic factors such as collective ownership, younger age and experience tend to influence producers to choose forward contract sales.

Woldie and Nuppenau (2011) have investigated the influence of vertical and horizontal integration on TCs and determined that TCs plays an important role in determining producers' market choice. For smooth and better integration as well as improving market integration, development of institutions that reduce TCs are suggested to be critical. In addition, they have suggested that this could be achieved by improved access of producers to market information that resulted in a more efficient price information flow. This would lead in turn to reduced TCs concerning ICs. They have found that establishing cooperatives at efficient locations also improves producers' bargaining power resulting in lower NCs.

Viana et al. (2012) have discovered that a hybrid form of horizontal integration and market integration are managing the supply chain transactions as a governance structure in the sheep farming industry. Horizontal integration has organized the producers and enabled the industry to obtain the required quota of sheep with the frequency needed, minimizing transportation costs. This has led to improved efficiency in the delivery confinement and finally slaughtering and preparation of the lamb for the single market. 
The required changes have to be carried out within the factory to enable the animals to be more efficiently slaughtered by a more efficient and confident labour force. In the horizontal integration, a medium rate of asset specificity, a higher frequency and an elevated level of uncertainty in ex-ante and ex-post monitoring transactions are perceived. In the market integration, however; low asset specificity, smaller transaction frequencies and a higher level of uncertainty in the ex-ante monitoring and negotiation transactions are observed. Uncertainty has prevailed mainly because the agents presented bounded rationality. However, this discrepancy has not led high levels of uncertainty since the margins chosen are quite restricted in creating reputation and formalizing long-term agreements. Therefore, opportunistic behaviour is lessened.

To highlight the contrasts between cooperative and non-cooperative transaction mechanisms, Lijia and Xuexi (2014) tried to measure the level of TCs in each mechanism. They have concluded that the cooperative transaction mechanism leads to a lower level of producers' TCs compared to non-cooperative transaction mechanism. The level of NCs and enforcement costs has differed in terms of buyers' expenditure on accommodation and buyers' breaking the contract. The varied delivery processes applied to each mechanism has led to different levels of transportation costs.

Failures in reducing TCs have been reported from projects on contract farming (Glover and Kusterer, 1990), cooperatives and producers' associations (Bijman and Wollni, 2008).

\section{Vertical Integration}

According to Allen and Lueck (2000), an important feature of successful agricultural organization is the extent to which producers are vertically coordinated, into processing, storage, and distribution.

Vertical integration is a hierarchical governance structure described as the "make-or-buy" paradigm of TCE (Walker and Weber, 1984). It has been often used as an alternative governance arrangement to anonymous spot market transactions. Williamson (1985) has defined it as the combination of two or more stages of a production-marketing chain under a single ownership. He has shown that price and quantity adjustments are more complete with vertical integration.

Vertical integration is as a function of technology, nature of transactions and market imperfections (Perry, 1989). It may bring many benefits such as reduced TCs within a supply chain, economies of scale, bargaining power counterbalances, improved information sharing that can result in innovation and differentiation (Lawrence et al, 1997). Next, it may emerge as an effective tool to reduce the asymmetric information and opportunism among the different parties that operate along the supply chain (Fundira, 2004). Moreover, a core TCE argument is that both asset specificity and environmental uncertainty favour vertical integration (Cadeaux and $\mathrm{Ng}, 2012$ ). In addition, it can transfer risk and control the production of its supplies and the distribution of its finished products (Mpoyi, 2003).

Williamson (1979) has also shown that vertical coordination mechanism minimizes the sum of TCs. He has argued that the choice of vertical coordination mechanism, from spot market to contract, strategic alliance or vertical integration, depends on the characteristics such as uncertainty, frequency and asset specificity of the transaction and on the institutional environment within which that transaction takes place. Thus, animal producers are required to adapt themselves to new sources of TCs.

Various studies have shown that vertical integration may provide reduced ICs, NCs and tangible TCs related to transport, storage, credit and market (Williamson, 1991; Staal et al., 1997; Hobbs and Young, 2000; Birthal et al., 2005). NCs can be lowered as a result of increased bargaining power (Woldie and Nuppenau, 2011). Moreover, TCs can be reduced by increasing size of producers (Kyeyamwa et al., 2008).

Geyskens et al. (2006) have found that asset specificity, volume uncertainty and behavioural uncertainty promote the choice of vertical integration over spot market. In contrast, in the face of technological uncertainty, spot market is preferred over vertical integration. In addition, the more there is an opportunism threat owing to differential bargaining power and behavioural uncertainty in recurring transactions, the greater the likelihood that vertical integration will be preferred (Memili et al., 2011).

On the other hand, vertical integration may bring an increase of operational control of MCs in order to prevent opportunism (Williamson, 1991; Peterson et al., 2001). Therefore, a higher degree of vertical integration through a relation-based strategic alliance is more appropriate to economize the TCs, and 
finally may help the producers to compete more effectively for their share in the market (Jordaan and Grove, 2013).

\section{RESEARCH METHODOLODY}

It is realized that TCE, in its current content, is neither able to fully explain nor solve any of the problems of small-scale animal producers, spot markets and/or animal husbandry sector operating in Central Anatolia, Turkey. This study is carried out in order to identify the attributes influencing TCs; and determine whether establishing an IMP plant in the region can solve the "commercial helplessness" of these producers.

To achieve these goals, Structural Equation Modelling (SEM) is employed in order to test the following hypotheses:

-Hypothesis 1 (H1): "Commercial helplessness" is significantly and positively influenced by "need for plant".

-Hypothesis 2 (H2): "Commercial helplessness" is significantly and positively influenced by "sales channel mistrust”.

-Hypothesis 3 (H3): "Transaction cost" is significantly and negatively influenced by "sales channel convenience".

-Hypothesis 4 (H4): "Transaction cost" is significantly and positively influenced by "commercial helplessness".

This study was conducted in the Anatolian city of Eskişehir. The rationale of choosing study population and sample from Eskişehir is mainly due to its location. Eskişehir is located near the two biggest cities of Turkey by population, namely Istanbul and Ankara, where there is high demand for carcass meat. Secondly, majority of the animal producers in Eskişehir were small-scaled. Thirdly, it was easier to reach and communicate with small-scale animal producers in Eskişehir than the other Anatolian cities.

The sample size consisted of eight hundred-and-fifty-seven small-scale animal producers selected randomly. A pre-test questionnaire was developed and tested by face-to-face meetings with these smallscale animal producers and key role players within the animal husbandry sector. Data collection was carried out with the assistance of agricultural engineers and vets. In the light of the findings obtained from literature reviewing on TCs, they were asked about the problems they commonly faced in the sector.

Producers have complained that existing slaughterhouses in the region do not meet their expectations. Thus, the number of those slaughterhouses has been decreasing in the region. The need for IMP Plant is a prior issue for the region. Other problems included the producer's access to labour force, access to adequate equipment, access to legal information, low professional knowledge, transporting animals on bad roads and access to price information; opportunistic buyer's bargaining power, animal's probability of getting ill, death and losing weight during transport and at the marketplace, various costs resulting from health reports, contracts, commissions, accommodation and quality control; sales to the loss, nontrustworthy buyers. They were then classified into transportation risk, market channel mistrust, market channel inconvenience, sectoral unfeasibility and market helplessness. It was noted that these problems were commonly faced by animal producers but at different levels.

Prior to formal implementation of survey, a panel of four experts was designed that comprised a group of academicians and two key role players from industry to solicit their opinions and assess the contents of the questionnaire. Some questions were put differently for animal producers' better understanding and thus, to minimize bias. The final questionnaire captured information on animal producer's demographic information, socio-economic condition, current condition at spot markets. A five-level Likert scale was used with " 1 " corresponding to "strongly disagree" and "5" corresponding to "strongly agree".

\section{RESEARCH FRAMEWORK}

\section{Commercial Helplessness}

Small-scale animal producers have stated during face-to-face meetings that they are not satisfied with their businesses at all although they are selling their animals at high prices (Yasan, 2018). The author called this paradox as "commercial helplessness". Yasan (2018) has defined "commercial helplessness" as the clear weakened ability of small-scale animal producers to achieve their full potential. He has 
described it as a set of following three dimensions, namely unfeasibility in animal husbandry sector, transportation risks from farm to marketplace, and market helplessness experienced by small-scale animal producers.

Ross (1924) is the first scholar to use the term "commercial helplessness". He has stated that animal producer has to some extend become a victim of his own occupation through his dependence upon those he supplies and also even more so on those he relies on to supply his domestics and makes his domestic life viable. Very little has changed to the advantage of animal producers until today. They are still the victims of their former circumstances but only now, the working conditions of spot markets show no additional drive for producers to live and rear.

"Commercial helplessness" has been operationalized by using the following constructs: sectoral unfeasibility, transportation risk and market helplessness, as suggested by Yasan (2018). This study will also investigate its relationship with "sale channel mistrust" and "need for plant".

\section{Transaction Cost}

"Transaction cost" is operationalized by using the following constructs: contract / lawyer costs, accommodation costs, weighing (scale) costs, commission costs, quality control costs and health report costs.

\section{Sectoral Unfeasibility}

"Sectoral unfeasibility" is operationalized by using the following constructs: producers' poor access to skilled labour, producers' purchase and use of inadequate technical equipment, bad physical infrastructure during transport and at spot market (e.g. road, electricity, water and sewage), lack of producers' information about legal regulations, producers' insufficient professional breeding knowledge/experience.

Matungul et al. (2001) has suggested that small-scale producers often lack skilled labour force and tend to produce with the most economical costs of resource and labour. Fenwick and Lyne (1999), Delgado (1999), Key et al. (2000), Matungul et al. (2001), Gong et al. (2007), Broderick et al. (2011), Koatla (2012), Martey et al. (2012), Lijia and Xuexi (2014) have shown that unavailability and nonpresence of labour force quality may have adverse implications for productivity of small-scale animal producers.

Matungul et al. (2001), Gong et al. (2007), Shiimi (2009) and Koatla (2012), in their studies, have described lack of adequate equipment and appropriate technology among the constraints faced producers in developing countries.

Matungul et al. (2001), Makhura (2001), Ruijs et al. (2004), Gong et al. (2007), Kyeyamwa et al. (2008), Koatla (2012), Martey et al. (2012) and Lijia and Xuexi (2014), in their studies, have stated that bad infrastructure is positively correlated with transportation costs. Jagwe et al. (2010) have highlighted that small-scale animal producers are usually located in remote areas and that they suffer from poor transportation facilities and poor infrastructure. They have concluded that these conditions add to the high TCs which are an impediment to enable many transactions to take place. Kyeyamwa et al. (2008) have discussed poor infrastructure emerging as a significant variable in his model and concluded that poor infrastructure decreases the likelihood of farmers participating in spot market as opposed to farm gate. Ruijs et al. (2004) have stated that reductions in transportation costs have a major effect on the functioning of food markets in developing countries. They have considered quality of road infrastructure as a significant factor and conclude that improvements reduce transportation costs substantially. They have concluded that animal producers are generally discouraged from using the roads with poor infrastructure since it is too costly. Makhura (2001) has stated that transport networks, i.e. more accessible roads and vehicles, facilitate access to spot markets. Ruijs et al. (2004) have suggested that better road conditions decrease cattle prices and improve transport flows.

Vernimmen et al. (2000), Matungul et al. (2001), Gong et al. (2006), Shiimi (2009) and Jordaan and Grove (2013), in their studies, have suggested that being informed about government policies is an important factor in market participation for small-scale animal producers in developing countries since producers often lack information about their rights and the legislative frameworks.

Crase and Dollery (1999) have argued that the limitations of humans may be such that they lack the skills, knowledge and intelligence to process information on products even within a bounded rationality 
Journal of Global Strategic Management | V. 12 | N. 2 | 2018-December| isma.info | 005- 026 | DOI: 10.20460/JGSM.2019.265 framework. Hence, the more time and energy spent on searching for market information, the higher the ICs (Gong et al., 2007).

Matungul et al. (2001, Gong et al. (2007), Kyeyamwa et al. (2008), Shiimi (2009), Broderick et al. (2011), Arinloye et al. (2012), Koatla (2012), Jordaan and Grove (2013) and Lijia and Xuexi (2014), in their studies, have shown that more experience in animal husbandry results in lower TCs for small-scale animal producers.

Table 2. Meta-analysis of Dimensions and Variables

\begin{tabular}{|c|c|c|c|}
\hline $\begin{array}{l}\text { Scale } \\
\text { Dimensions }\end{array}$ & & Items & References \\
\hline \multirow[t]{5}{*}{$\begin{array}{l}\text { Sectoral } \\
\text { Unfeasibility }\end{array}$} & a1 & Unfeasibility due to poor access to skilled labour. & $\begin{array}{l}\text { Fenwick and Lyne (1999), Delgado (1999), Key et } \\
\text { al. (2000), Matungul et al. (2001), Gong et al. } \\
\text { (2007), Broderick et al. (2011), Koatla (2012), } \\
\text { Martey et al. (2012), Lijia and Xuexi (2014). }\end{array}$ \\
\hline & $\mathrm{a} 2$ & $\begin{array}{l}\text { Unfeasibility due to inadequate technical } \\
\text { equipment. }\end{array}$ & $\begin{array}{l}\text { Matungul et al. (2001), Gong et al. (2007), Shiimi } \\
\text { (2009), Koatla (2012). }\end{array}$ \\
\hline & a3 & $\begin{array}{l}\text { Unfeasibility due to bad physical infrastructure } \\
\text { during transport and at spot market (road, } \\
\text { electricity, telecommunications, water, sewage, } \\
\text { etc.). }\end{array}$ & $\begin{array}{l}\text { Matungul et al. (2001), Makhura (2001), Ruijs et al. } \\
\text { (2004), Gong et al. (2007), Kyeyamwa et al. (2008), } \\
\text { Koatla (2012), Martey et al. (2012), Lijia and Xuexi } \\
\text { (2014). }\end{array}$ \\
\hline & $\mathrm{a} 4$ & $\begin{array}{l}\text { Unfeasibility due to (lack of information about) } \\
\text { legal regulations. }\end{array}$ & $\begin{array}{l}\text { Vernimmen et al. (2000), Matungul et al. (2001), } \\
\text { Gong et al. (2006), Shiimi (2009), Jordaan and } \\
\text { Grove (2013). }\end{array}$ \\
\hline & a5 & $\begin{array}{l}\text { Unfeasibility due to producers' insufficient } \\
\text { professional animal husbandry } \\
\text { knowledge/experience. }\end{array}$ & $\begin{array}{l}\text { Crase and Dollery (1999), Matungul et al. (2001, } \\
\text { Gong et al. (2007), Kyeyamwa et al. (2008), Shiimi } \\
\text { (2009), Broderick et al. (2011), Arinloye et al. } \\
\text { (2012), Koatla (2012), Jordaan and Grove (2013), } \\
\text { Lijia and Xuexi (2014). }\end{array}$ \\
\hline \multirow[t]{3}{*}{$\begin{array}{l}\text { Transportation } \\
\text { Risk }\end{array}$} & d1 & Risk of weight and value loss during transport. & $\begin{array}{l}\text { Hobbs (1997), De Bruyn et al. (2001), Von Bailey } \\
\text { and Hunnicutt (2002). }\end{array}$ \\
\hline & $\mathrm{d} 2$ & $\begin{array}{l}\text { Risk of stress / accident / injury / livestock waste } \\
\text { during transport. }\end{array}$ & Hobbs (1996a), Hobbs (1997), Ndoro et al. (2015). \\
\hline & d3 & $\begin{array}{l}\text { Risk of animal illness during transport or at } \\
\text { marketplace. }\end{array}$ & Hobbs (1997). \\
\hline \multirow[t]{3}{*}{$\begin{array}{l}\text { Market } \\
\text { Helplessness }\end{array}$} & h1 & $\begin{array}{l}\text { Feeling helpless due to not being able to find } \\
\text { enough buyers in spot market. }\end{array}$ & Woldie and Nuppenau (2011). \\
\hline & h2 & $\begin{array}{l}\text { Feeling helpless due to selling animals cheaply in } \\
\text { order not to bring them back to farm. }\end{array}$ & Hobbs (1997). \\
\hline & h3 & $\begin{array}{l}\text { Feeling helpless due to not being able to sell } \\
\text { animals in spot market and bringing them back to } \\
\text { farm. }\end{array}$ & $\begin{array}{l}\text { Hobbs (1997), De Bruyn et al. (2001), Nkhori } \\
\text { (2004). }\end{array}$ \\
\hline \multirow{6}{*}{$\begin{array}{l}\text { Sales Channel } \\
\text { Mistrust }\end{array}$} & b1 & Been deceived in sales. & Hobbs (1997). \\
\hline & b2 & Complain about the sale to the loss. & Hobbs (1997). \\
\hline & b3 & Own animals claimed to have poor quality. & Gong et al. (2007). \\
\hline & b4 & Profitable sales channel & Woldie and Nuppenau (2011). \\
\hline & b5 & $\begin{array}{l}\text { Honest and trustworthy sales channel where sellers } \\
\text { cannot be deceived. }\end{array}$ & Hobbs (1997); Woldie and Nuppenau (2011). \\
\hline & b6 & $\begin{array}{l}\text { Feeling uncomfortable about not being able to } \\
\text { predict own earnings at spot market. }\end{array}$ & Hobbs (1997); Woldie and Nuppenau (2011). \\
\hline \multirow[t]{6}{*}{$\begin{array}{l}\text { Transaction } \\
\text { Cost }\end{array}$} & $\mathrm{c} 1$ & Contract / lawyer costs. & $\begin{array}{l}\text { Schroeder et al. (1993), Hobbs (1997), De Bruyn et } \\
\text { al. (2001), Woldie and Nuppenau (2011), Viana et } \\
\text { al. (2012), Lijia and Xuexi (2014). }\end{array}$ \\
\hline & $\mathrm{c} 2$ & Accommodation costs. & Hobbs (1997), Lijia and Xuexi (2014). \\
\hline & c3 & Weighing (scale) costs. & $\begin{array}{l}\text { Hobbs (1997), Delgado (1999), Chvosta et al. } \\
\text { (2001), Shiferaw et al. (2006). }\end{array}$ \\
\hline & $\mathrm{c} 4$ & Commission costs. & $\begin{array}{l}\text { Hobbs (1997), Von Bailey and Hunnicutt (2002), } \\
\text { Schmitz et al. (2003). }\end{array}$ \\
\hline & $\mathrm{c} 5$ & Quality control costs. & $\begin{array}{l}\text { Hobbs (1996a), Hobbs (1996b), Gong et al. (2007), } \\
\text { Viana et al. (2012). }\end{array}$ \\
\hline & c6 & Health report costs. & Gong et al. (2007), Chamberlain and Jayne (2011). \\
\hline Sales Channel & f1 & Easily accessible sales channel. & Gebremedhin et al., (2007) \\
\hline
\end{tabular}




\begin{tabular}{|l|l|l|l|}
\hline Convenience & f2 & A sales channel where it is easy to sell. & $\begin{array}{l}\text { Makhura (2001), Dossa et al. (2008), Millar and } \\
\text { Photakoun (2008), Mertz et al. (2009), Ampaire and } \\
\text { Rothschild (2010), Namonje-Kapembwa et al. } \\
\text { (2016). }\end{array}$ \\
\hline & f3 & A sales channel where it is easy to negotiate. & Gong et al. (2007). \\
\hline Need for Plant & g1 & $\begin{array}{l}\text { Need for an integrated meat-processing plant in the } \\
\text { region. }\end{array}$ & $\begin{array}{l}\text { Gwin and Thiboumery (2012), Gwin, Thiboumery } \\
\text { and Stillman (2013). }\end{array}$ \\
\hline & g2 & $\begin{array}{l}\text { An integrated meat-processing plant may provide } \\
\text { financial benefit to the region. }\end{array}$ & Gwin and Thiboumery (2012). \\
\hline & g3 & $\begin{array}{l}\text { An integrated meat-processing plant may provide } \\
\text { financial benefit to animal producers. }\end{array}$ & $\begin{array}{l}\text { Delgado et al. (2001), Zezima (2010), Gwin and } \\
\text { Thiboumery (2012), Gwin et al. (2013), Stillman et } \\
\text { al. (2013). }\end{array}$ \\
\hline
\end{tabular}

\section{Transportation Risk}

"Transportation risk" is operationalized by using the following constructs: weight and value loss during transport, stress / accident / injury / livestock waste during transport and animal illness during transport and/or in the spot market.

Hobbs (1996a), Hobbs (1997), De Bruyn et al. (2001), Von Bailey and Hunnicutt (2002). Hobbs (1997), De Bruyn et al. (2001), Von Bailey and Hunnicutt (2002) and Ndoro et al. (2015), in their studies, have shown that transportation risk is associated with poor welfare and high TCs.

Leach (1982) has defined transportation of animals as an unnatural activity that inevitably exposes them to a variety of hazards. She has stated that microclimate, space allowance and location within trailer, transport duration, distance and vehicle speed are important factors of animal welfare during transport. Moreover, she has added that animals in transport are usually confined to a restricted amount of space, in close contact with other animals, and without access to feed or water, which inherently imposed restrictions. Goldhawk (2014) has suggested that these restrictions are related to the behavioural adaptations and metabolic responses that animals can perform to cope with acute changes in environmental conditions during transport. Moberg (2000) has investigated the way how animals adapt and cope with challenges during transport in terms of integrated physiological and behavioural responses. Deshazer et al. (2009) have stated that acute changes in temperature primarily elicit behavioural changes, such as changing posture, feed consumption, and distance from other animals followed by changes in metabolism to cope with maintaining core body temperature. McEwen (1998) has concluded that animals become pathological (i.e. ill and/or start losing carcass value) or even die when these response systems are faulty or overloaded.

\section{Market Helplessness}

"Market helplessness" is operationalized as: the problem of not being able to find enough buyers in spot market; the problem of not being able to sell their animals and incur the expense of transportation of cattle back to the farm; and that they felt obliged to sell their animals cheaply rather than incur the expense of transportation of cattle back to the farm; and that they sold their animals cheaply rather than incur the expense of transportation of cattle back to the farm.

Hobbs (1997), De Bruyn et al. (2001), Nkhori (2004) and Woldie and Nuppenau (2011), in their studies, have shown that animal producers are not happy with the number of animals they sell in the spot markets. They often lack market information and are not able to sell their animals on the price they ask for.

Shepherd (1997) has stated that small-scale producers often lack information about the prices of products both at the local level and at final consumer's level, about quality requirements, about places and best periods for selling their animals, about potential customers and about production in other areas. He has concluded that this information may be obtained through contacts with other members of the community, but the accuracy of information cannot be guaranteed since those parties might have opportunistic behaviour.

Shepherd (1997) has suggested that the cost of obtaining market information and demand is a fundamental TC for small-scale animal producers. Farace et al. (1977) have defined information in terms of the reduction of uncertainty and concluded that greater uncertainty will cause greater need for information. Delgado (1999) has concluded that a decrease in the cost of information may reduce TCs. 
Kyeyamwa et al. (2008) has stated that knowledge of market information is a significant determinant of market choice. Moreover, the time invested in completing a transaction is a crucial OC which reflects potential success of attending the market and selling his animals. They have concluded that poor communications constrict efficient access to market information, a range of varied strategies for successful access and effective communication networks.

\section{Sales Channel Mistrust}

"Sales channel mistrust" is operationalized as: the problem of being deceived in sales; the problem of owning animals claimed to have poor quality by buyers; the problem of feeling uncomfortable about not being able to predict own earnings at spot market; the problem of not being able to find an honest and trustworthy sales channel where sellers are not deceived; complaining about selling animals to the loss; and the problem of not knowing any profitable sales channel.

Hobbs (1997), Gong et al. (2007) and Woldie and Nuppenau (2011), in their studies, have shown that animal producers often suffer from the difficulties in finding a profitable sales channel. In this case, trust plays a crucial role. The role of trust between producers and various potential buyers such as agents, cooperatives, wholesalers and retailers affect producer's decision-making in choosing the optimal transaction channel with better selling price during the sales process (Rorstad et al. 2007; Williamson and Ghani, 2012; Lijia and Xuexi, 2014).

For small-scale animal producers, trust is important in governing exchange and sufficient to reduce TCs related to monitoring and enforcement (Gebremedhin et al., 2007). Dyer and Chu (2003) express that the trustworthiness is a crucial source of competitive advantage in the sales process. Producers are more likely to transact with those buyers who are prepared to invest in their relationship with the producer (Batt, 2003). A good reputation and trustworthiness of buyers increases producers' commitment to the pertaining sales channel. This is mainly because trust reduces opportunistic behaviour and promotes cooperation and commitment in the relationship (Woldie and Nuppeneu, 2011).

\section{Sales Channel Convenience}

"Sales channel convenience" is operationalized as the easiness of accessing a sales channel and the easiness of negotiating and selling there.

Sales channel can be regarded as the process of transferring particular products or services from producers to consumers (El-Ansary and Stern, 1972). Ensign (2006) has suggested that how channel members perceive, build, and deal with relationships that exist within the channel are crucial.

Makhura (2001), Dossa et al. (2008), Millar and Photakoun (2008), Mertz et al. (2009), Ampaire and Rothschild (2010) and Namonje-Kapembwa et al. (2016), in their studies, have mentioned sales channels where animal producers feel it is relatively easier to access, participate, negotiate and sell.

Gebremedhin et al. (2004) suggest that TCs limit accessing a sales channel. Several authors have commonly found that ICs related to difficulty in finding information and time spent researching price information, and NCs expressed in time spent in negotiation process, low bargaining power, and transport cost, depending on the distance from markets negatively influence the producer's choice to sell at formal market (Hobbs, 1996b; Hobbs, 1997; Key et al.., 2000; Hudson and Lusk, 2004; Ruijs et al., 2004; Gong et al., 2007; Kyeyamwa et al., 2008; Broderick et al., 2011; Woldie and Nuppenau, 2011; Lijia and Xuexi, 2012; Jordaan and Grove, 2013).

Goetz (1992) and Nkhori (2004) have found that having access to information on the price offered in a specific market increases the easiness of selling in that market.

Gebremedhin et al. (2007) have stated that the price is often negotiated between seller and buyer; however, it is affected by several factors: age, weigh, colour, body condition of animals, value of hides and skins, distance of travel to sell animals and ease of bringing animals back with them.

\section{Need for Plant}

Institutions (i.e. legal, financial, market information, quality measurement or regulatory policy) have evolved to minimize transaction costs by governing the transaction environment (Hobbs, 2003). However, in the absence of such effective institutions in Eskişehir, high TCs have led to market failure of animal 

producers. Thus, they have recognized the need to vertically integrate with an IMP plant to market their animals and internalize high TCs arising from spot market transactions.

"Need for an IMP plant" is operationalized as the future financial benefits to the surrounding region and animal producers once the IMP is established.

Gwin, Thiboumery and Stillman (2013) have stated that IMPs are essential links in local meat supply chains. They have determined that effective communication is crucial for farmer-processor commitments about scheduling and services, costs and pricing, meat quality, and market conditions to develop and maintain strong business partnership. They have concluded that small processors often lack the steady and consistent business required for profitability.

Delgado et al. (2001) have suggested small-scale animal producers be vertically linked with processors and marketers of perishable products. They stated that the integration of small-scale producers and IMP plants would combine the environmental and poverty-alleviation benefits of small-scale animal production with the economies of scale and human health benefits that can be had from larger scale processing.

Fearne (1998) has listed the potential benefits of having such a hierarchical governance structure as: improved market access; secured access to larger volume segment of market; improved communications, i.e. higher levels of sharing experience, market information, production methods and knowledge; higher profit margins; greater discipline; lower pressure to reduce prices to consumers; less competition between individual firms within supply chain; higher traceability of animals; more inspected feeding; higher animal health and welfare; consistent higher food quality and safety, recognized farm assurance; more secure means of transport and handling; full documentation and monitoring of animals through every stage of the rearing and meat processing chain.

Goetz (1992) has suggested that access to processing technology has a positive effect on the total output sold in the market. Therefore, producers should commit to providing consistent throughput of animals to process, and processors should commit to providing consistent, high-quality processing services. Zezima (2010) has argued that producers need access to appropriately scaled IMP plants with the skills, inspection status, and reliability to prepare these products safely, legally, and to customer specifications. He has determined that limited processing infrastructure restricts the supply of local meat.

Gwin and Thiboumery (2012) have stated that development and maintenance of business commitments between producers and processors as well as policy work are essentially important in IMP plants.

\section{ANALYSIS}

The procedure of analysis can be outlined as follows (Yasan, 2018): First, the structural and measurement factors to construct a hypothetical model were defined. Second, the hypothetical model was continuously verified, developed and improved with profound modifications by using SEM. Consequently, the final model was interpreted, validated and introduced to the literature. Statistical analysis was performed by using SPSS and AMOS software packages.

\section{Sample Adequacy}

Kaiser-Meyer-Olkin (KMO) test and Bartlett's Test of Sphericity were applied to test the sample adequacy for factor analysis. First, the Kaiser-Meyer-Olkin (KMO) was conducted in order to find the proportion of variance in the variables that might be caused by underlying factors (Hayton et al., 2004). As the $\mathrm{KMO}$ of measuring sampling adequacy was 0.879 , i.e. greater than 0.500 , strong partial correlation in the data was exhibited (Hair et al., 2010). Second, Bartlett's Test of Specificity showed the strength of the relation among the variables and that there existed significant relationships among variables at. $\mathrm{p}<0.001$ (Hair et al., 2010). Therefore, from both test results, it was concluded that correlation matrix was explained in the sample group and added that the sample was suitable for factor analysis.

\section{Estimation}

Maximum Likelihood Factor Estimation method was employed in order to fit the model to data (Hair et al., 2010). In order to check normality, skewness and kurtosis values of data variables were examined. Since these values are between $(+2,-2)$, it is assumed that the data variables are distributed normally (Garson, 2012; George and Mallery, 2010). Then, optimal estimates for factor loadings and unique variances were obtained. The values at the diagonal of the anti-image correlation matrix were measured. 
Journal of Global Strategic Management | V. 12 | N. 2 | 2018-December| isma.info | 005- 026 | DOI: 10.20460/JGSM.2019.265

Next, the multivariate normal likelihood function was maximized by yielding desired similarity between the observed and model-implied co-variances (Yasan, 2018). In addition, the results were verified by Varimax Rotation procedure that attempted to yield a simple structure that each of the factors tended to load highly on some of the factors and had low loadings on the other factors (Hair et al., 2010).

\section{Exploratory Factor Analysis}

To discover the number and nature of latent variables that explains the variation and covariation in a set of measured variables, Exploratory Factor Analysis (EFA) was conducted. It grouped different variables which might address similar features. The factor structure of each variable in the scale was compared with the theoretical predicted factor structure. Factor analysis was repeated after each variable subtraction. Therefore, the communality value, i.e. each variable's proportion of variability that is explained by the factors, was investigated. Since communality values greater than 0.50 should be considered for further analysis, variables with communality values lower than 0.50 , were discarded since these were outlier variables (Hair et al., 2010). Factor loadings of all variables exceeded 0.50 with the exception of 4 (0.465). Since the value $(0.465)$ was close to the desired level $(0.50)$, the $c 4$ variable was decided not to be excluded from the scale.

Consequently, an item from the "transaction cost" factor (c4) was excluded from the scale due to its low factor loading. Therefore, a scale consisting of six items for "sales channel mistrust", five items for "sectoral unfeasibility", three items for "sales channel convenience", three items for "transportation risk", six items from "transaction cost", three items for "need for plant" was developed.

\section{Reliability and Internal Consistency}

Table 3 shows that all items had factor loading level greater than 0.70 , resulting in a high degree of reliability for the analysis. The total explained variance was measured to be $63.613 \%$. Cronbach's alpha reliability coefficients values were measured to be greater than 0.70 for all the remained variables (Table 3). This indicated the acceptable level of internal consistency (Hair et al., 2010).

Table 3. Factor Loading Levels (EFA)

\begin{tabular}{|c|c|c|c|c|c|c|c|c|}
\hline \multirow{2}{*}{ Factor } & \multirow{2}{*}{ Item } & \multicolumn{7}{|c|}{ Factor Loading Levels } \\
\hline & & 1 & 2 & 3 & 4 & 5 & 6 & 7 \\
\hline \multirow{5}{*}{ Sectoral Unfeasibility } & a1 & 0,595 & & & & & & \\
\hline & $\mathrm{a} 2$ & 0,755 & & & & & & \\
\hline & a3 & 0,796 & & & & & & \\
\hline & a4 & 0,706 & & & & & & \\
\hline & a5 & 0,689 & & & & & & \\
\hline \multirow{6}{*}{ Sales Channel Mistrust } & b1 & & 0,728 & & & & & \\
\hline & b2 & & 0,611 & & & & & \\
\hline & b3 & & 0,614 & & & & & \\
\hline & $\mathrm{b} 4$ & & 0,539 & & & & & \\
\hline & b5 & & 0,671 & & & & & \\
\hline & b6 & & 0,660 & & & & & \\
\hline \multirow{6}{*}{ Transaction Cost } & $\mathrm{c} 1$ & & & 0,703 & & & & \\
\hline & c2 & & & \begin{tabular}{|l|l|}
0,709 \\
\end{tabular} & & & & \\
\hline & $\mathrm{c} 3$ & & & 0,709 & & & & \\
\hline & $\mathrm{c} 4$ & & & 0,471 & & & & \\
\hline & $\mathrm{c} 5$ & & & 0,803 & & & & \\
\hline & c6 & & & 0,643 & & & & \\
\hline \multirow{3}{*}{ Transportation Risk } & $\mathrm{d} 1$ & & & & 0,736 & & & \\
\hline & d2 & & & & 0,850 & & & \\
\hline & $\mathrm{d} 3$ & & & & 0,764 & & & \\
\hline \multirow{3}{*}{ Market Helplessness } & $\mathrm{h} 1$ & & & & & 0,632 & & \\
\hline & $\mathrm{h} 2$ & & & & & 0,763 & & \\
\hline & h3 & & & & & 0,723 & & \\
\hline \multirow{3}{*}{ Sales Channel Convenience } & $\mathrm{f} 1$ & & & & & & 0,652 & \\
\hline & $\mathrm{f} 2$ & & & & & & 0,982 & \\
\hline & $\mathrm{f} 3$ & & & & & & 0,581 & \\
\hline \multirow{3}{*}{ Need for a Plant } & g1 & & & & & & & 0,545 \\
\hline & g2 & & & & & & & 0,925 \\
\hline & g3 & & & & & & & 0,849 \\
\hline \multicolumn{2}{|l|}{ Explained Variance $(\%)$} & 12.187 & 9.808 & 11.396 & 9.049 & 7.294 & 6.649 & 7.229 \\
\hline \multicolumn{2}{|l|}{ Total Explained Variance (\%) } & \multicolumn{7}{|l|}{63.613} \\
\hline
\end{tabular}




\section{Confirmatory Factor Analysis}

Construct validity for the three dimensions was assessed by Confirmatory Factor Analysis (CFA). Four items (b3, b6, c4 and c6) were excluded from the scale due to its low factor loading level. All variables were found to be statistically significant. Factor loading level of each item was found to be greater than 0.50 (Table 4). Similarly, average loading level of each item was found to be greater than 0.70 (Table 4).

Then, a second-order CFA was carried out. Table 4 shows the items of the final structural equation model with their indicators. Factor loading level of all items were greater than 0.700 . The significance level of each variable was found to be at the desired level (Table 4).

Table 4. Factor Loading Levels (CFA)

\begin{tabular}{|c|c|c|c|c|c|c|c|}
\hline \multirow[b]{2}{*}{ Factor } & \multirow[b]{2}{*}{ Item } & \multicolumn{3}{|l|}{ First-order CFA } & \multicolumn{3}{|c|}{ Second-order CFA } \\
\hline & & $\begin{array}{l}\text { Factor Loading } \\
\text { Level }\end{array}$ & \begin{tabular}{|l|} 
Standardized \\
Factor Loading \\
Level
\end{tabular} & $\mathbf{t}$ & \begin{tabular}{|l|} 
Factor \\
Loading \\
Level
\end{tabular} & $\begin{array}{l}\text { Standardized } \\
\text { Factor Loading } \\
\text { Level }\end{array}$ & $\mathbf{t}$ \\
\hline \multirow{3}{*}{$\begin{array}{l}\text { Transportation } \\
\text { Risk }\end{array}$} & $\mathrm{d} 1$ & 1 & 0,977 & & \multirow{3}{*}{1} & \multirow{3}{*}{0,805} & \multirow{3}{*}{25,799} \\
\hline & $\mathrm{d} 2$ & 1,018 & 0,932 & 50,857 & & & \\
\hline & d3 & 1,049 & 0,972 & 46,691 & & & \\
\hline \multirow{3}{*}{\begin{tabular}{|l} 
Market \\
Helplessness
\end{tabular}} & h1 & 1 & 0,744 & & \multirow{3}{*}{0,603} & \multirow{3}{*}{0,815} & \multirow{3}{*}{17,698} \\
\hline & h2 & 1,224 & 0,91 & 25,821 & & & \\
\hline & h3 & 1,104 & 0,839 & 24,331 & & & \\
\hline \multirow{4}{*}{$\begin{array}{l}\text { Sectoral } \\
\text { Unfeasibility }\end{array}$} & a1 & 0,89 & 0,703 & 16,642 & \multirow{4}{*}{0,575} & \multirow{4}{*}{0,773} & \multirow{4}{*}{16,029} \\
\hline & $\mathrm{a} 2$ & 1 & 0,737 & & & & \\
\hline & a3 & 1,12 & 0,738 & 26,076 & & & \\
\hline & a5 & 1,319 & 0,837 & 19,454 & & & \\
\hline \multirow{4}{*}{$\begin{array}{l}\text { Sales Channel } \\
\text { Mistrust }\end{array}$} & b1 & 1 & 0,495 & & & & \\
\hline & b2 & 1,564 & 0,862 & 7,775 & & & \\
\hline & $\mathrm{b} 4$ & 0,995 & 0,587 & 13,023 & & & \\
\hline & b5 & 1,449 & 0,885 & 8,228 & & & \\
\hline \multirow{4}{*}{ Transaction Cost } & $\mathrm{c} 1$ & 1,288 & 0,848 & 23,805 & & & \\
\hline & $\mathrm{c} 2$ & 1,282 & 0,819 & 23,223 & & & \\
\hline & $\mathrm{c} 3$ & 1,071 & 0,687 & 22,551 & & & \\
\hline & $\mathrm{c} 5$ & 1 & 0,762 & & & & \\
\hline \multirow{3}{*}{ Need for a Plant } & $\mathrm{g} 1$ & 1 & 0,618 & & & & \\
\hline & $\mathrm{g} 2$ & 1,063 & 0,907 & 11,726 & & & \\
\hline & g3 & 1,24 & 0,873 & 18,051 & & & \\
\hline \multirow{3}{*}{$\begin{array}{l}\text { Sales Channel } \\
\text { Convenience }\end{array}$} & f1 & 1 & 0,689 & & & & \\
\hline & $\mathrm{f} 2$ & 1,452 & 0,991 & 17,842 & & & \\
\hline & f3 & 0,869 & 0,594 & 16,812 & & & \\
\hline
\end{tabular}

\section{Goodness of Fit}

The next step in scale validation was to examine the Goodness-of-Fit Index (GFI) of the overall CFA model. The analysis included the use of GFI measures such as the Relative Chi-squared Test $\left(\mathrm{X}^{2} / \mathrm{do}\right)$ the Root Mean Square Error of Approximation (RMSEA), Non-Normed Fit Index (NNFI), Tucker-Lewis Index (TLI), Comparative Fit Index (CFI) and Parsimonious Normed Fit Index (PNFI), suggested by Kline (2005) and Hu and Bentley (1999).

To achieve the recommended Goodness-of-Fit Index (GFI) value (Table 5), several iterations were made. As shown in Table 5, the resulting model based on the necessary fitting measures was appropriately supported.

The $\mathrm{X}^{2} /$ do degree of freedom ratio, giving a value of 4.659 , indicated acceptable fit to the data. The value of the absolute fit parameter, i.e. RMSEA, is 0.066 , which was smaller than the accepted level of 0.080 . The two incremental fit parameters, i.e. TLI and CFI yielded values of 0.919 and 0.931 , respectively 
Journal of Global Strategic Management | V. 12 | N. 2 | 2018-December| isma.info | 005- 026 | DOI: 10.20460/JGSM.2019.265 which also supported the acceptable model fit. In addition, the PNFI value of 0.775 provided sufficient evidence that the fit between the measurement model and data was acceptable.

Table 5. Fitting Measures

\begin{tabular}{|l|r|r|r|}
\hline Measures & Good Fit & Acceptable Level & Final Model (CFA) \\
\hline$X^{2} / \mathrm{df}$ & $1<\mathrm{X}^{2} / \mathrm{df} \leq 3$ & $3<\mathrm{X}^{2} / \mathrm{df}<5$ & 4.659 \\
\hline RMSEA & $<0.06$ & $<0.07$ & 0.066 \\
\hline GFI & $>0.95$ & $>0.90$ & 0.899 \\
\hline NNFI-TLI & $>0.95$ & $>0.90$ & 0.919 \\
\hline CFI & $>0.95$ & $>0.90$ & 0.931 \\
\hline PNFI & $>0.50 *$ & & 0.775 \\
\hline
\end{tabular}

*valid when GFI, NNFI and CFI values are altogether at the 0.900 level.

\section{Validity and Reliability}

Next, convergent validity was evaluated for the three factors using Average Variance Extracted (AVE) and Composite Reliability (CR) suggested by Fornell and Larcker (1981) and, Bagozzi and Yi (1988). All factor loadings should be significant and greater than 0.70; AVE value item each item should exceed the variance due to measurement error for that item (i.e., AVE should be greater than 0.50) and CR value of each item should be greater than 0.70 . AVE and CR values are shown in Table 6. CR values for all factors were measured to be greater than 0,7 .

Similarly, AVE values for all factors with the exception of that of sales channel mistrust (0.489), exceeded 0.50. However, since the value $(0.489)$ is close to the desired level $(0.50)$, the factor was decided not to be excluded from the model. When the CFA factor loadings were examined, all the variables were found to be statistically significant. The factor loadings and factor averages were above 0.5 and 0.7 , respectively. These results yielded the convergence validity of the research scale factors (Table 6).

Table 6. Correlation, Validity and Reliability values

\begin{tabular}{|c|c|c|c|c|c|c|c|c|c|c|}
\hline Factors & $\begin{array}{l}\text { Cronbach's } \\
\text { Alpha }\end{array}$ & CR & AVE & $\begin{array}{l}\text { Market } \\
\text { Helplessness }\end{array}$ & \begin{tabular}{|l|} 
Market \\
Helplessness
\end{tabular} & $\begin{array}{l}\text { Market } \\
\text { Helplessness }\end{array}$ & $\begin{array}{l}\text { Market } \\
\text { Helplessness }\end{array}$ & $\begin{array}{l}\text { Need for } \\
\text { a Plant }\end{array}$ & $\begin{array}{l}\text { Sales } \\
\text { Channel } \\
\text { Convenience }\end{array}$ & $\begin{array}{l}\text { Transportation } \\
\text { Risk }\end{array}$ \\
\hline $\begin{array}{l}\text { Market } \\
\text { Helplessness }\end{array}$ & 0,867 & 0,871 & 0,694 & 0,833 & & & & & & \\
\hline $\begin{array}{l}\text { Sectoral } \\
\text { Unfeasibility }\end{array}$ & 0,871 & 0,859 & 0,551 & $0,608 * * *$ & 0,743 & & & & & \\
\hline $\begin{array}{l}\text { Sales Channel } \\
\text { Mistrust }\end{array}$ & 0,775 & 0,791 & 0,489 & $0,283 * * *$ & $0,174 * * *$ & 0,700 & & & & \\
\hline $\begin{array}{l}\text { Transaction } \\
\text { Cost }\end{array}$ & 0,868 & 0,863 & 0,612 & $0,580 * * *$ & $0,520 * * *$ & $0,256 * * *$ & 0,783 & & & \\
\hline $\begin{array}{l}\text { Need for a } \\
\text { Plant }\end{array}$ & 0,804 & 0,851 & 0,660 & $0,147 * * *$ & $0,153 * * *$ & $0,096 *$ & $-0,023 \mathrm{~ns}$ & 0,813 & & \\
\hline $\begin{array}{l}\text { Sales Channel } \\
\text { Convenience }\end{array}$ & 0,787 & 0,812 & 0,601 & $-0,060 \mathrm{~ns}$ & $0,047 \mathrm{~ns}$ & $-0,222 * * *$ & $-0,205 * * *$ & $0,123 * *$ & 0,775 & \\
\hline $\begin{array}{l}\text { Transportation } \\
\text { Risk }\end{array}$ & 0,958 & 0,969 & 0,913 & $0,662 * * *$ & $0,637 * * *$ & $0,324 * * *$ & $0,411 * * *$ & $0,331 * * *$ & $0,089^{*}$ & 0,956 \\
\hline
\end{tabular}

Hart et al. (2012) has defined divergent validity as the degree to which the measure of an item differs from the results of unrelated items. Hair et al. (2010) has measured it as the square roots of AVEs should be higher than the correlations between items. The square root of AVE values which were found to be greater than the relevant coefficient values, are represented on the diagonal in Table 6.

Both convergent validity and discriminant validity analyses showed that the scale was valid. In addition, validity and reliability of the factorial constructs were found to be at the desired levels (Table 6).

\section{FINDINGS}

Research findings are summarized in Table 7. "Commercial helplessness" was significantly influenced by "need for plant" $(\beta=0.232, \mathrm{p}<0,001)$ and "sales channel mistrust" $(\beta=0.296, \mathrm{p}<0.001)$ in the positive 
Journal of Global Strategic Management | V. 12 | N. 2 | 2018-December| isma.info | 005- 026 | DOI: 10.20460/JGSM.2019.265 direction. Moreover, "sales channel convenience" had a significant effect on "transaction cost" in the negative direction $(\beta=-0,214, p<0.001)$. In addition, "commercial helplessness" $(\beta=0,613, p<0,001)$ was found to significantly affect "transaction cost" in the positive direction. According to these findings, all hypotheses $\mathrm{H} 1, \mathrm{H} 2, \mathrm{H} 3$ and $\mathrm{H} 4$ were supported based on the information derived from the data collected from small-scale animal producers.

Table 7. SEM Results

\begin{tabular}{|c|c|c|c|c|c|c|}
\hline Hypotheses & Independent Variable & & Dependent Variable & Standardized $\beta$ & $\mathrm{t}$ & $\mathrm{p}$ \\
\hline H1 & Need for a Plant & $\rightarrow$ & Commercial Helplessness & 0,232 *** & 5,716 & 0,000 \\
\hline $\mathrm{H} 2$ & Sales Channel Mistrust & $\rightarrow$ & Commercial Helplessness & $0,296 * * *$ & 7,404 & 0,000 \\
\hline $\mathrm{H} 3$ & Sales Channel Convenience & $\rightarrow$ & Transaction Cost & $-0,214 * * *$ & $-6,531$ & 0,000 \\
\hline $\mathrm{H} 4$ & Commercial Helplessness & $\rightarrow$ & Transaction Cost & $0,613 * * *$ & 14,486 & 0,000 \\
\hline
\end{tabular}

The final structural equation model showing the second-order CFA factor loadings are depicted in Figure 1. The same figure also shows the standardized coefficient values between factors and their corresponding items.

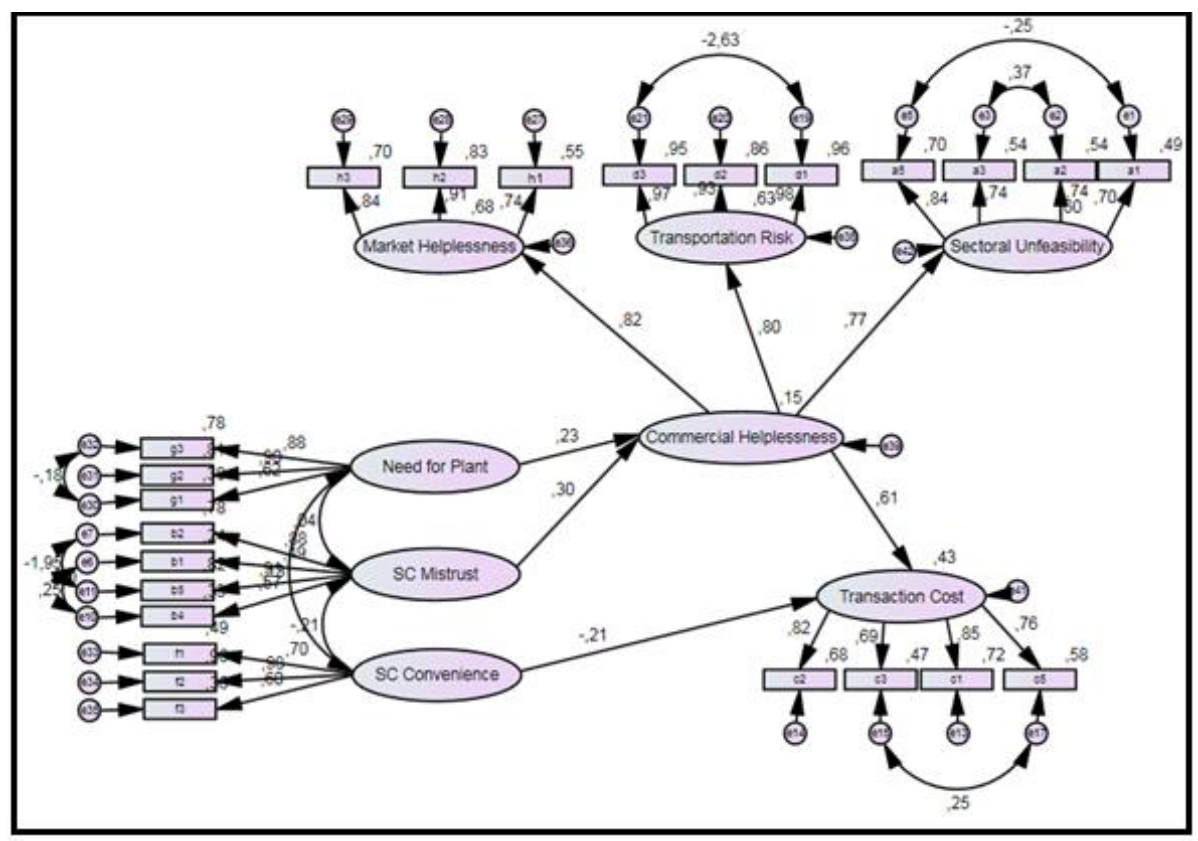

Abbreviation: $\mathrm{SC}=$ Sales Channel

Figure 1. Final structural equation model with all coefficient values

\section{CONCLUSION}

In this study, the author proposes a pioneering "need for an IMP plant" model to the TCE literature. Initiating from the theoretical construction based on relevant literature and face-to-face meetings, the author aimed to examine a model specific to explain the relationships of attributes affecting helplessness" and "need for plant" by using data from eight hundred-and-fifty-seven Turkish small-scale livestock producers.

This article is a field research report elaborating on many and diverse problems of real everyday smallscale animal producers experience in the animal husbandry sector in present-day Turkey. It presents a detailed study of inefficiencies, unfeasibility, risks and disadvantages of spot markets and commercial helplessness felt by small-scale of animal producers.

In this study, the author investigated the relationship between "need for plant" and commercial helplessness", "sales channel mistrust" and commercial helplessness", "sales channel inconvenience" and "transaction cost", and "commercial helplessness" and "transaction cost" using CFA.

The results of CFA can be summarized as follows: 
- "Need for an IMP plant" has a direct, positive and significant effect on "commercial helplessness". There is a positive correlation $(0.232)$ between these dimensions.

- "Sales channel mistrust" directly, significantly and positively affected "commercial helplessness".

- "Sales channel convenience" has a direct, significant but negative effect on "transaction cost".

- "Commercial helplessness" is a direct, significant and positive predictor of "transaction cost".

In the ranking of direct effect size, "sales channel mistrust" was the major factor (0.296) affecting commercial helplessness. "Sales channel convenience" (-0.21) and "commercial helplessness" (0.61) were the two influencing factors of "transaction cost" in order. "Commercial helplessness" generates a markedly direct and positive effect on "transaction cost" (0.61), the highest among all the effects.

The results obtained from the analyses suggest that the producers favour vertical integration with an IMP plant in the region as "need for plant" and "sales channel mistrust" are found to be two important indicators of their "commercial helplessness".

The survey results show that establishing an IMP plant will decrease TCs and producer's commercial helplessness. The decrease in TCs will lower the meat price. With the IMP, the volume of meat trade will increase in the region. A more reliable environment for producers and buyers will be created. This will to increase the speed of commercial transactions and profitability. It is also expected that employment opportunities and commercial activity will increase. These will have a positive impact on the animal husbandry sector and regional refinance.

This study was conducted by incorporating the TCE. When different management and organisational theories are the basis of this study, different models may be obtained, depending on the range of variables employed during the study. In addition, different dimensions may arise while conducting the same study in developed or other developing economies.

This study was carried out to highlight the shortcomings at many levels of the animal husbandry and marketing. It is believed that this insight will be helpful not only to fully explain animal producers' problems; improve their circumstances, but also result in driving the small-scale animal producers to vertically integrate with the IMP plants proposed-to-be established countrywide.

Certain limitations to the present study need to be addressed. First, the author experienced difficulties with small-scale animal producers while getting replies about their annual production practice, income, education level, knowledge and experience. Since they had never kept accounting records, the author could not review these data. Therefore, this study was based on small-scale animal producers' perception related to their annual profit and TCs. Second, the author was not able to make interview with the buyers. They were scattered and did not have any professional association in the region.

Further studies will focus on a new model incorporating the relationship between small-scale animal producers' commercial helplessness and their financial management ability to use and access to financial instruments. 


\section{REFERENCES}

Abraham, K., and Taylor, S. (2001). Firms' use of outside contractors: Theory and evidence. Journal of Labour Economics, 14 (3): 394-424.

Allen, D.W., and Lueck, D. (2000). A transaction cost primer on farm organization. Canadian Journal of Agricultural Economics, 48 (4): 643-652.

Alene, A.D., Manyong, V.M., Omanya, G., Mignouna, H.D., Bokanga, M., and Odhiambo, G. (2008). Smallholder market participation under transactions costs: Maize supply and fertilizer demand in Kenya. Food policy, 33 (4): 318-328.

Ampaire, A., and Rothschild, M.F. (2010). Effects of training and facilitation of farmers in Uganda on livestock development. Livestock Research for Rural Development, 22 (7): 1-9.

Arinloye, D.D.A., Hagelaar, G., Linnemann, A.R., Pascucci, S., Coulibaly, O., Omta, O.S.F.W., and Van Boekel, A.J.S. (2012). Multi-governance choices by smallholder farmers in the pineapple supply chain in Benin: An application of transaction cost theory. African Journal of Business Management, 6 (38): 10320-10331.

Arrow, K.J. (1969). The organization of economic activity: Issues pertinent to the choice of market versus nonmarket allocation. The analysis and evaluation of public expenditure: The PPB system, $91^{\text {st }}$ Congress of the Joint Economic Committee: 59-73.

Bagozzi, R. P., and Yi, Y. (1988). On the evaluation of structural equation models. Journal of the Academy of Marketing Science, 16 (1): 74-94.

Barney, J.B., and Hesterly, W. (2006). Organizational economics: Understanding the relationship between organizations and economic analysis. The SAGE Handbook of Organization Studies. London, U.K.: Sage Publications.

Barney, J., Wright, M., and Ketchen, M. (2001). The resource-based view of the firm: ten years after 1991. Journal of Management, 27 (6): 625-641.

Barringer, B.R., and Harrison, J.S. (2000). Walking a tightrope: Creating value through inter organizational relationships. Journal of Management, 26 (3): 367-403.

Bartle, J.R. (2001). A transaction cost model of state government. Annual Conference of the Association for Budgeting and Financial Management, Washington DC, USA: January 19.

Batt, P. (2003). Building trust between growers and market agents. Supply Chain Management: An International Journal, 8 (1): 65-78.

Birthal, P.S., Joshi, P.K. and Gulati, A. (2005). Vertical coordination in high-value food commodities: Implications for smallholders. MTID Discussion Paper, 85. Washington D.C., USA: International Food Policy Research Institute Publications.

Broderick, S., Wright, V., and Kristiansen, P. (2011). Cross-case analysis of producer-driven marketing channels in Australia. British Food Journal, 113 (10): 1217-1228.

Butler, P.T., Hall, W., Hanna, A.M., Mendonca, L., Auguste, B., Manyika, J., and Sahay, A. (1997). A revolution in interaction. McKinsey Quarterly, 1: 3-14.

Cadeaux, J., and Ng, A. (2012). Environmental uncertainty and forward integration in marketing: Theory and meta-analysis. European Journal of Marketing, 46 (1-2): 5-30.

Chamberlin, J., and Jayne, T.S. (2013). Unpacking the meaning of 'market access': Evidence from rural Kenya. World Development, 41 (1): 245-264.

Charlebois, S., and Camp, R.D. (2007). Environmental uncertainty and vertical integration in a small business network: The case of Natural Valley Farms Inc. Journal of Enterprising Communities: People and Places in the Global Economy, 1 (3): 252-267.

Chen, M.S., Chang, H. J., Huang, C.W., and Liao, C.N. (2006). Channel coordination and transaction cost: A game-theoretic analysis. Industrial Marketing Management, 35 (2): 178-190. 
Journal of Global Strategic Management | V. 12 | N. 2 | 2018-December| isma.info | 005- 026 | DOI: 10.20460/JGSM.2019.265

Chvosta, J., Rucker, R. R., and Watts, M. J. (2001). Transaction costs and cattle marketing: the information content of seller-provided presale data at bull auctions. American Journal of Agricultural Economics, 83 (2): 286-301.

Coase, R.H. (1937). The nature of the firm. Economica, 4 (16): 386-405.

Coase, R.H. (1960). The problem of social cost. In Classic papers in natural resource economics. London, U.K.: Palgrave Macmillan Publications.

Coetzee, G. (1995). Credit. In R. Singini and J.M. Van Rooyen (Eds.), Serving small-scale farmers: an evaluation of DBSA's farmer support programmes. South Africa: Development Bank of Southern Africa Publications.

Crase, L., and Dollery, B. (1999). The valuation of market information from livestock selling complexes. Australian Journal of Agricultural and Resource Economics, 43(2): 195-208.

De Bruyn, P., De Bruyn, J.N., Vink, N., and Kirsten, J.F. (2001). How transaction costs influence cattle marketing decisions in the northern communal areas of Namibia. Agrekon, 40(3): 405-425.

Delgado, C.L. (1995). Agricultural diversification and export promotion in sub-Saharan Africa. Food policy, 20 (3): 225-243.

Delgado, C. (1999). Sources of growth in smallholder agriculture in sub-Saharan Africa: The role of vertical integration of smallholders with processors and marketers of high-value added items. Agrekon, 38: $165-189$.

Delgado, C., Rosegrant, M., Steinfeld, H., Ehui, S., and Courbois, C. (2001). Livestock to 2020: The next food revolution. Outlook on Agriculture, 30 (1): 27-29.

Deshazer, J.A., Hahn, G.L., and Xin, H. (2009). Basic principles of the thermal environment and livestock energetics characterization of livestock responses. In J.A. Deshazer, (Ed.), Livestock energetics and thermal environmental management. St Joseph, USA: American Society of Agricultural Engineers Publications.

Dorward, A., Kydd, J., Poulton, C., and Bezemer, D. (2009). Coordination risk and cost impacts on economic development in poor rural areas. The Journal of Development Studies, 45 (7): 1093-1112.

Dossa, L.H., Rischkowsky, B., Birner, R., and Wollny, C. (2008). Socio-economic determinants of keeping goats and sheep by rural people in southern Benin. Agriculture and Human Values, 25 (4): 581592.

Drabenstott, M. (1995). Agricultural industrialization: Implications for economic development and public policy. Journal of Agricultural and Applied Economics, 27 (1): 13-20.

Dyer, J.H., and Chu, W. (2003). The role of trust-worthiness in reducing transaction costs and improving performance. Organization Science, 14 (1): 57-68.

Eggertson, T. (1990). Economic Behavior and Institutions. Cambridge, U.K.: Cambridge University Press.

El-Ansary, A.I., and Stern, L.W. (1972). Power measurement in the distribution channel. Journal of Retailing, 48 (1): 47-52.

Ensign, P.C. (2006). International channels of distribution: A classification system for analysing research studies. Multinational Business Review, 14(3): 95-120.

Farace, R. V., Monge, P. R., and Russell, H.M. (1977). Communicating and organizing. Reading, U.S.A.: Addison-Wesley Publications.

Fearne, A. (1998). The evolution of partnerships in the meat supply chain: Insights from the British beef industry. Supply Chain Management, 3 (4): 214-223.

Fenwick, L.J., and Lyne, M.C. (1999). The relative importance of liquidity and other constraints inhibiting the growth of small-scale farming in KwaZulu-Natal. Development Southern Africa, 16 (1): 141-151.

Fiani, R. (2000). A teoria dos custos de transacao, In D. Kupfer and L. Hasenclever (Eds.), Economia industrial: Fundamentos teoricos e praticas no Brasil. Rio de Janeiro, Brazil: 276-306. 
Journal of Global Strategic Management | V. 12 | N. 2 | 2018-December| isma.info | 005- 026 | DOI: 10.20460/JGSM.2019.265 Field, A. (2009). Discovering statistics using SPSS. London, U.K.: Sage Publications.

Food and Agriculture Organization (FAO) (2009a). The state of agricultural commodity markets: High food prices and the food crisis: experiences and lessons learned. Rome: FAO Publications.

Food and Agriculture Organization (FAO) (2009b). The state of food and agriculture: Livestock in the balance. Rome: FAO Publications.

Fornell, C., and Larcker, D.F. (1981). Evaluating structural equation models with unobservable variables and measurement error. Journal of Marketing Research, 18 (1): 39-50.

Fundira, T. (2004). A transaction cost analysis of the fruit supply chain in South Africa: A case study approach. Doctoral Dissertation.

Garson, G.D. (2012). Testing statistical assumptions. North Carolina: Statistical Associates Publications.

Gebremedhin, B., Hoekstra, D., and Jemaneh, S. (2007). Heading towards commercialization. The case of live animal marketing in Ethiopia. IPMS Working Paper, 5, Nairobi, Kenya: International Livestock Research Institute.

Gebremedhin, B., Smale, M., and Pender, J. (2004). Determinants of cereal diversity in villages in Northern Ethiopia, In M. Smale (Ed.), Valuing crop biodiversity: On-farm genetic resources and economic change, Abingdon: CABI Publications, 177-191.

George, D., and Mallery, M. (2010). SPSS for Windows Step by Step: A Simple Guide and Reference, 17.0 update. Boston: Pearson Publications.

Geyskens, I., Steenkamp, J.B.E., and Kumar, N. (2006). Make, buy or ally: A transaction cost theory meta-analysis. Academy of Management Journal, 49 (3): 519-543.

Globerman, S., and Schwindt, R. (1986). The organization of vertical related transactions in the Canadian forest products industry. Journal of Economic Behaviour and Organization, 7 (2): 199-212.

Goetz, S. (1992). A selectivity model of household food marketing behaviour in Sub-Saharan Africa. American Journal of Agricultural Economics, 74 (2) :444-452.

Goldhawk, C.A. (2014). Microclimate during beef cattle transport: effects of transportation management and relationship to indicators of animal welfare. Doctoral Dissertation.

Gong, W., Parton, K., Zhou, Z., and Cox, R.J. (2006). Marketing Channel Selection by Cattle Farmers in China: A Transaction Cost Approach. International Conference on Emerging China: Internal Challenges and Global Implications, Melbourne: Association for Chinese Economics Studies Australia.

Gong, W., Parton, K., Cox, R.J., and Zhou, Z. (2007). Transaction costs and cattle farmers' choice of marketing channels in China. Management Research New, 30 (1): 47-56.

Gulati, R., and Singh, H. (1998). The architecture of cooperation: Managing coordination costs and appropriation concerns in strategic alliances. Administrative Science Quarterly, 43 (4): 781-814.

Glover, D. (1990). Contract farming and out-grower schemes in east and southern Africa. Journal of Agricultural Economics. 41 (3): 303-315.

Gwin, L., and Thiboumery, A. (2012). Local meat processing: Business strategies and policy angles. Vermont Law Review, 37 (6), 987-1006.

Gwin, L., Thiboumery, A., and Stillman, R. (2013). Local meat and poultry processing: The importance of business commitments for long-term viability. Report 262222, United States: Department of Agriculture - Economic Research Service.

Hair, J.F., Anderson, R.E., Babin, B.J., and Black, W.C. (2010). Multivariate data analysis: A global perspective. New Jersey, NJ: Pearson Publishers.

Hart, S.L., Albiani, J.J., Crangle, C.J., Torbit, L.A., and Varma, M.G. (2012). Development and assessment of the constipation-related disability scale. Alimentary Pharmacology and Therapeutics, 35 (1): 183-192.

Hayton, J.C., Allen, D.G., and Scarpello, V. (2004). Factor retention decisions in exploratory factor analysis: A tutorial on parallel analysis. Organizational Research Methods, 7 (2): 191-205. 
Journal of Global Strategic Management | V. 12 | N. 2 | 2018-December| isma.info | 005- 026 | DOI: 10.20460/JGSM.2019.265

Hobbs, J.E. (1996a). Transaction costs and slaughter cattle procurement: processors' selection of supply channels. Agribusiness, 12 (6): 509-523.

Hobbs, J.E. (1996b). A transaction cost approach to supply chain management. Supply Chain Management: An International Journal, 1 (2): 15-27.

Hobbs, J.E. (1997). Measuring the importance of transaction costs in cattle marketing. American Journal of Agricultural Economics, 79 (4): 1083-1095.

Hobbs, J.E. (2003). Information, incentives and institutions in the agri-food sector. Canadian Journal of Agricultural Economics, 51 (3): 413-429.

Hobbs, J.E., and Young, L.M. (2000). Closer vertical coordination in agri-food supply chains: A conceptual framework and some preliminary evidence. Supply Chain Management: An International Journal, 5 (3): 131-143.

Hobbs, J.E., Weseen, S., and Kerr, W.A. (2012). Transaction costs, hold-ups and governance in ethanol supply chains. Conference of International Association of Agricultural Economists. Brazil: August 18-24.

Hu, L.T., and Bentler, P.M. (1999). Cut-off criteria for fit indexes in covariance structure analysis: Conventional criteria versus new alternatives. Structural Equation Modelling: A Multidisciplinary Journal, 6 (1): 1-55.

Hudson, D., and Lusk, J. (2004). Risk and transactions cost in contracting: Results from a choice-based experiment. Journal of Agricultural and Food Industrial Organization, 2 (1): 1-17.

Hutt, M., Stafford, E., Walker, B., and Renigen, P. (2000). Defining the social network of a strategic alliance. MIT Sloan Management Review, 41 (2): 51-62.

Iimi, A. (2007). Infrastructure and trade preferences for the livestock sector: Empirical evidence from the beef in Africa. Washington DC, U.S.A.: World Bank Publications.

Jabbar, M., Benin, S., Gabre-Madhin, E., and Paulos, Z. (2006). Trader behaviour and performance in live animal marketing in rural Ethiopian markets. International Association of Agricultural Economists Conference, Gold Coast, Australia: August 12-18.

Jaffee, S., and Morton, J. (1995). Marketing Africa's high-value foods: Comparative experiences of an emergent private sector. Dubuque: U.S.A.: Kendall Hunt Publications.

Jagwe, J.N. (2011). The impact of transaction costs on the participation of smallholder farmers and intermediaries in the banana markets of Burundi, Democratic Republic of Congo and Rwanda. Doctoral Dissertation.

Jordaan, H., and Grove, B. (2013). Transaction cost analysis of raisins marketing by emerging farmers from Eksteenskuil, South Africa. Agrekon, 52 (4): 21-42.

Key, N., Sadoulet, E., and Janvry, A. (2000). Transactions costs and agricultural household supply response. American Journal of Agricultural Economics, 82 (2): 245-259.

Kline, R.B. (2005). Principles and practice of Structural Equation Modelling. New York, U.S.A.: The Guilford Publications.

Koatla (2012). Mainstreaming small-scale farmers in Qwaqwa, Free State Province, South Africa. Doctoral Dissertation.

Kyeyamwa, H., Speelman, S., Van Huylenbroeck, G., Opuda-Asibo, J., and Verbeke, W. (2008). Raising offtake from cattle grazed on natural rangelands in sub-Saharan Africa: A transaction cost economics approach. Agricultural Economics, 39 (1): 63-72.

Lawrence, J.D., Rhodes, V.J., Grimes, G.A., and Hayenga, M.L. (1997). Vertical coordination in the US pork industry: Status, motivations, and expectations. Agribusiness: An International Journal, 13 (1): 21 31.

Leach, T. (1982). Physiology of transportation of cattle. Current Topics in Veterinary Medicine and Animal Science, 18: 57-74

Lijia, W. and Xuexi, H. (2014). Grower's selling behaviour: Transaction cost comparison analysis. Agricultural Economics Review, 15 (2): 5-28. 
Journal of Global Strategic Management | V. 12 | N. 2 | 2018-December| isma.info | 005- 026 | DOI: 10.20460/JGSM.2019.265 MacInnis, B. (2004). Transaction costs and organic marketing: Evidence from US organic producers. Annual Meeting of American Agricultural Economics Association. Denver, U.S.A.: August 1-4.

Makhura, M.T. (2001). Overcoming transaction costs barriers to market participation of smallholder farmers in the northern province of South Africa. Doctoral Dissertation.

Martey, E., Al-Hassan, R. M., and Kuwornu, J. K. (2012). Commercialization of smallholder agriculture in Ghana: A Tobit regression analysis. African Journal of Agricultural Research, 7 (14): 2131-2141.

Matungul, P.M.; Lyne, M.C., and Ortmann, G.F. (2001). Transaction costs and crop marketing in the communal areas of Impendle and Swayimana, KwaZulu-Natal. Development Southern Africa, 18 (3): 347-363.

McEwen, B. (1998). Stress, adaptation, and disease: Allostasis and allostatic load. Annals of the New York Academy of Sciences, 840 (1): 33-44.

Memili, E., Chrisman, J.J., and Chua, J.H. (2011). Transaction costs and outsourcing decisions in smalland medium-sized family firms. Family Business Review, 24 (1): 47-61.

Menard, C. (2004). The economics of hybrid organizations. Journal of Institutional and Theoretical Economics, 160 (3): 345-376.

Mertz, O., Mbow, C., Reenberg, A., and Diouf, A. (2009). Farmers' perceptions of climate change and agricultural adaptation strategies in rural Sahel. Environmental Management, 43 (5): 804-816.

Millar, J., and Photakoun, V. (2008). Livestock development and poverty alleviation: Revolution or evolution for upland livelihoods in Lao PDR. International Journal of Agricultural Sustainability, 6 (1): 89-102.

Moberg, G. (2000). Biological response to stress: Implications for animal welfare. In G. Moberg and J.A. Mench, Eds., The biology of animal stress: Basic principles and implications for animal welfare. U.K.: CABI Publications.

Mpoyi, R.T. (2003). Vertical integration: strategic characteristics and competitive implications. Competitiveness Review: An International Business Journal, 13 (1): 44-55.

Namonje-Kapembwa, T., Chiwawa, H., and Sitko, N. (2016). Value-chain analysis of goats in Zambia: Challenges and opportunities of linking smallholders to markets, Working paper 117. Zambia: Indaba Agricultural Policy Research Institute.

Ndoro, J.T., Mudhara, M., and Chimonyo, M. (2015). Farmers' choice of cattle marketing channels under transaction cost in rural South Africa: a multinomial logit model. African Journal of Range \& Forage Science, 32 (4), 243-252.

Nkhori, P.A. (2004). The impact of transaction costs on the choice of cattle markets in Mahalapye district. Doctoral Dissertation.

North, D. (1997). Transaction costs through time. In C. Menard (Ed.), Transaction cost economics: Recent developments. Vermont, U.S.A.: Edward Elgard Publications.

Perry, M.K. (1989). Vertical integration: Determinants and effects. In R. Schmalensee, and R.D. Willig, (Eds.), Handbook of industrial organization. North-Holland: Elsevier Science Publications.

Peterson, H.C., Wysocki, A., and Harsh, S.B. (2001). Strategic choice along the vertical coordination continuum. The International Food and Agribusiness Management Review, 4 (2): 149-166.

Rorstad, P. K., Vatn, A., and Kvakkestad, V. (2007). Why do transaction costs of agricultural policies vary. Agricultural economics, 36 (1): 1-11.

Ross, E.A. (1924). The allaying of town-country conflict. Journal of Social Forces, 3 (1): 15-21.

Ruijs, A., Schweigman, C., and Lutz, C. (2004). The impact of transport- and transaction-cost reductions on food markets in developing countries. Agricultural Economics, 31 (2-3): 219-228.

Schmitz, T.G., Moss, C. B., and Schmitz, A. (2003). Marketing channels compete for US stocker cattle. Journal of Agribusiness, 21 (2): 131-148.

Schroeder, T.C., Jones, R., Mintert, J., and Barkley, A.P. (1993). The impact of forward contracting on fed cattle transaction prices. Review of Agricultural Economics, 15 (2): 325-337. 
Journal of Global Strategic Management | V. 12 | N. 2 | 2018-December| isma.info | 005- 026 | DOI: 10.20460/JGSM.2019.265

Selli, F., Eraslan, İ.H., Chowdhury, D., and Sukumar, A. (2010). International competitiveness: Analysis of Turkish animal husbandry: An empirical study in GAP region. Enterprise Risk Management, 2 (1): 100-114.

Shepherd, A. (1997). Market information services: Theory and practice, 125. Rome, Italy: FAO Publications.

Shiferaw, B., Obare, G., and Muricho, G. (2006). Rural institutions and producer organizations in imperfect markets: Experiences from producer marketing groups in semi-arid Eastern Kenya.

Socioeconomics and Policy Working Paper Series, 23. India: International Crops Research Institute for the Semi-Arid Tropics.

Shiimi, T. (2009). Transaction costs and cattle farmers' choice of marketing channel in North Central Namibia. Doctoral Dissertation.

Singh, N. (2008). Transaction costs, information technology and development. Indian Growth and Development Review, 1(2): 212-236. Staal, S., Delgado, C., and Nicholson, C. (1997). Smallholder dairy under transactions costs in East Africa. World Development, 25 (5): 779-794.

Vernimmen, T., Verbeke, W., and Van Huylenbroeck, G. (2000). Transaction cost analysis of outsourcing farm administration by Belgian farmers. European Review of Agricultural Economics, 27 (3): 325-345.

Viana, J.G., Silveira, V.C., Arbage, A.P., and Machado, J.A. (2012). Governance and transaction costs in the sheep production chain in Rio Grande do Sul, Brazil. African Journal of Business Management, 6 (11): 4376-4385.

Vilpoux, O.F. (2013). The supply of raw materials to agribusinesses in Brazil: Development of a conceptual model. International Journal of Management, 30 (4): 355-373.

Von Bailey, D., and Hunnicutt, L. (2002). The role of transaction costs in market selection: market selection in commercial feeder cattle operations. Annual Meeting of the American Agricultural Economics Association, Long Beach, CA: July 28-31.

Walker, G., and Weber, D. (1984). A transaction cost approach to make-or-buy decisions. Administrative Science Quarterly, 29 (3): 373-391.

Walter, C.K., Boeckenstedt, R., and Chase, C. (2007). Transaction cost case studies for six Iowa food producers: Leopold Centre Publications and Papers, 164 (6), 1-22.

Williamson, O.E. (1975). Markets and hierarchies. New York: The Free Press Publications.

Williamson, O.E. (1979). Assessing vertical market restrictions: Antitrust ramifications of the transaction cost approach. University of Pennsylvania Law Review, 127 (4): 953-993.

Williamson, O.E. (1985). The economic institutions of capitalism. New York, U.S.A.: Collier Macmillan Publications.

Williamson, O.E. (1991). Comparative economic organization: The analysis of discrete structural alternatives. Administrative Science Quarterly, 36 (2): 269-296.

Williamson, O.E. (1998). Transaction cost economics: How it works; where it is headed. De Economist, 146 (1): 23-58.

Williamson, O., and Ghani, T. (2012). Transaction cost economics and its uses in marketing. Journal of the Academy of Marketing Science, 40 (1): 74-85.

Woldie, G.A., and Nuppenau, E.A. (2011). A contribution to transaction costs. Agribusiness, 27 (4): 493 508.

Yasan, A. (2018). Beyond transaction cost economics: Commercial helplessness of small-scale animal producers in Turkey. Proceedings of the 14th International Strategic Management Conference. Prague: Czechia, July 12-14: 611-621.

Zezima, K. (2010). Push to eat local food is hampered by shortage. March 27, USA: New York Times. 